\title{
PENYISIHAN LOGAM TIMBAL (Pb) DAN SENG (Zn) PADA LUMPUR WASTEWATER TREATMENT PLANT DAN ABU BOILER INDUSTRI REFINERY DAN BIODIESEL MINYAK KELAPA SAWIT DENGAN COMPOSTING
}

\author{
LEADING METAL (Pb) AND ZINC (Zn) IN MUD WASTEWATER TREATMENT PLANT AND \\ BOILER ASH INDUSTRIAL REFINERY AND BIODIESEL OIL PALM OIL WITH \\ COMPOSTING
}

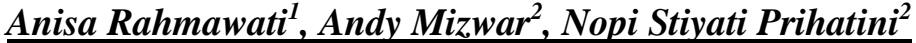 \\ ${ }^{I}$ Mahasiswa Program Studi Teknik Lingkungan, Fakultas Teknik, ULM \\ ${ }^{2}$ Dosen Program Studi Teknik Lingkungan, Fakultas Teknik, ULM \\ Jl. A. Yani Km 36, Banjarbaru, Kalimantan Selatan, Kode Pos70714, Indonesia \\ E-mail: aanisarahmawatii@gmail.com
}

\begin{abstract}
ABSTRAK
Limbah industri menjadi salah satu permasalahan yang perlu penangan khusus, salah satunya industri kelapa sawit. Limbah yang dihasilkan diantaranya adalah lumpur dan abu boiler. Limbah lumpur kelapa sawit masih mengandung beberapa bahan organik yang dapat dimanfaatkan sebagai bahan composting, sedangkan abu boiler merupakan limbah hasil proses pemanasan yang termasuk kedalam limbah B3 yang jika tidak diolah dengan baik akan menimbulkan permasalahan lingkungan. Penelitian ini dilakukan untuk mengetahui pengaruh variasi komposisi limbah lumpur industri kelapa sawit, abu boiler dan bahan organik terhadap penurunan logam $\mathrm{Pb}$ dan $\mathrm{Zn}$ dalam proses composting menggunakan sistem in vessel. Aktivitas mikroorganisme selama proses composting diyakini mampu mendegradasi logam berat. Hasil penelitian menunjukkan komposisi 50\% lumpur dan 50\% bahan organik merupakan komposisi bahan terbaik untuk menurunkan $\mathrm{Pb}$ dan $\mathrm{Zn}$.
\end{abstract}

Kata kunci : Lumpur WWTP, abu boiler, penurunan logam $\mathrm{Pb}$ dan $\mathrm{Zn}$

\section{PENDAHULUAN}

Di Indonesia industri kelapa sawit merupakan salah satu sektor industri yang cukup pesat perkembangannya. Perkembangan industry kelapa sawit membawa dampak baik terhadap perekonomian Negara, tetapi berpotensi menimbulkan pencemaran lingkungan jika penanganan limbah tidak dilakukan dengan baik (Putra, dkk., 2016).

Menurut Naibaho (1996), permasalahan lingkungan yang sering terjadi pada industri kelapa sawit disebabkan tidak sempurnanya penanganan limbah. Salah satu limbah kelapa sawit yang sulit ditangani adalah limbah lumpur / sludge effluent WWTP (Waste Water Treatment Plan). Limbah padat kelapa sawit (sludge) adalah endapan yang terbentuk di dasar bak pengendapan dalam 
sarana pengolahan limbah, dimana endapan memerlukan perlakuan khusus untuk meminimalisir dampak pencemaran lingkungan. Selain menghasilkan limbah lumpur, selama proses pemanasan industri kelapa sawit juga menghasilkan limbah abu boiler. Sesuai dengan yang tercantum dalam peraturan pemerintah nomor 101 tahun 2014, abu boiler juga termasuk dalam jenis limbah B3 dari sumber spesifik khusus karena timbunan abu dapat terbakar dengan sendirinya akibat dari gas metana $\left(\mathrm{CH}_{4}\right)$ yang dihasilkan dari timbunan abu tersebut, serta menimbulkan dampak buruk terhadap sistem pernafasan dan kulit (Lasryza dan Sawitri, 2012). Lumpur hasil dari Pengolahan Minyak Sawit (PMS) dapat diolah menjadi pupuk karena mengandung beberapa unsur yang diperlukan tanaman seperti nitrogen, kalium, fosfor, kalsium, dan magnesium (Darmawati, 2014). Menurut Priyambada (2015), limbah lumpur industri kelapa sawit dapat dimanfaatkan sebagai bahan kompos yang memiliki kuaitas sesuai SNI.

\section{METODE PENELITIAN}

\subsection{Lokasi dan Waktu Penelitian}

Penelitian dilakukan skala laboratorium yang dilaksanakan di Laboratorium Teknik Lingkungan, Fakultas Teknik Universitas Lambung Mangkurat Banjarbaru pada tanggal 01 mei hingga 04 Juni 2017 (selama 35 hari).

\subsection{Alat dan Bahan}

Alat yang digunakan pada penelitian ini terdiri dari komposter dengan sistem in vessel composting (Gambar 2.1) dan soil tester untuk mengukur suhu, kadar air dan $\mathrm{pH}$ setiap harinya. Bahan bahan yang diperlukan selama penelitian adalah lumpur WWTP, abu boiler serta sampah organik yang berupa sampah daun, serbuk gergaji dan serpihan kayu kecil.

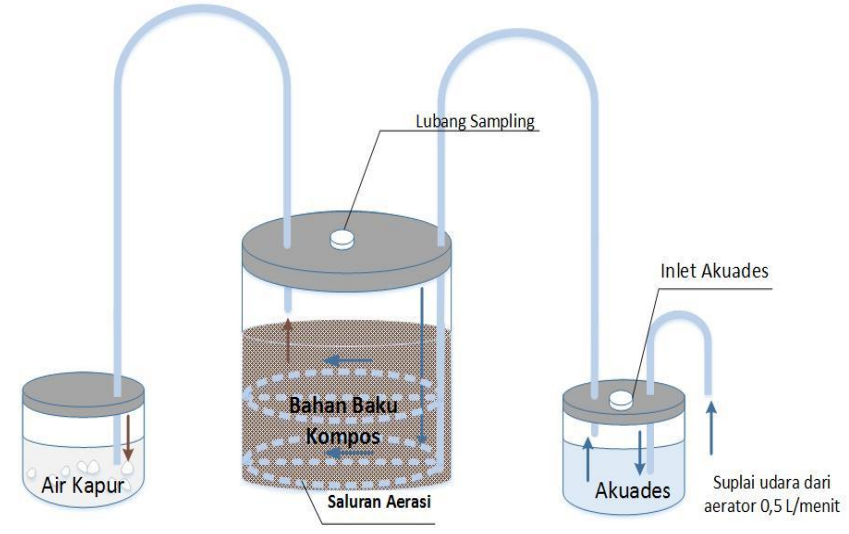

Gambar 2.1 Desain Komposter

Sumber : Mizwar dan Trihadiningrum, 2015

\subsection{Rencana Penelitian}

Penelitian ini dilakukan dengan memvariasikan bahan composting untuk mengetahui pengaruh komposisi bahan terhadap penurunan logam $\mathrm{Pb}$ dan $\mathrm{Zn}$. Variasi bahan composting disajikan dalam Tabel 2.1 
Tabel 2.1 Variasi Komposisi Bahan Composting

\begin{tabular}{ccccc}
\hline \multirow{2}{*}{$\begin{array}{c}\text { Kode } \\
\text { Reaktor }\end{array}$} & \multicolumn{3}{c}{ Komposisi } & \multirow{2}{*}{ Rasio C/N } \\
\cline { 2 - 4 } & $\begin{array}{c}\text { Lumpur } \\
\text { WWTP }\end{array}$ & $\begin{array}{c}\text { Abu } \\
\text { Boiler }\end{array}$ & Sampah Organik & \\
\hline R1 & $50 \%$ & $50 \%$ & $0 \%$ & 3.38 \\
R2 & $50 \%$ & $35 \%$ & $15 \%$ & 11.75 \\
R3 & $50 \%$ & $25 \%$ & $25 \%$ & 17,33 \\
R4 & $50 \%$ & $15 \%$ & $35 \%$ & 22,91 \\
R5 & $50 \%$ & $0 \%$ & $50 \%$ & 31,28 \\
R6 & $100 \%$ & $0 \%$ & $0 \%$ & 5,03 \\
\hline
\end{tabular}

Penelitian ini menggunakan proses composting dengan metode aerob sistem in vessel composting. Sistem in vessel composting merupakan proses composting yang dilakukan pada kontainer tertutup dengan sirkulasi udara melalui lubang pada selang yang telah diletakkan merata. Udara yang digunakan berasal dari penguapan air (moisture aeration) yang dialirkan dengan kecepatan 0,5 L/menit selama 24 jam. Moisture aeration tidak hanya berfungsi untuk menjaga ketersediaan oksigen tetapi juga menjaga kadar air selama composting tetap terjaga pada kisaran kondisi optimum $(50 \%$ - 60\%) (Sari, dkk, 2015).

Bioaktivator yang digunakan berupa EM-4 yang ditambahkan sebanyak 0,7\% dari berat total bahan composting (Priyambada, et al, 2015). Lama composting pada penelitian ini adalah 35 hari dengan dua kali pengulangan (duplo). Setiap 7 hari sekali dilakukan pengadukan bahan kompos dan pengambilan sampel uji. Parameter yang dianalisis pada setiap pengambilan sampel adalah $\mathrm{Pb}$ dan $\mathrm{Zn}$, sedangkan suhu, kadar air, dan pH diukur setiap hari untuk memantau kondisi composting.

\subsection{Cara Analisia Data}

Data pengamatan suhu, $\mathrm{pH}$, dan kadar air digunakan sebagai penentu kondisi composting. Data tersebut dijelaskan secara deskriptif disertai dengan grafik. Sedangkan data pengujian $\mathrm{Pb}$ dan $\mathrm{Zn}$ dianalisa dengan dua cara yaitu deskriptif dan statistik. Pembahasan deskriptif disertai tabel perhitungan guna menganalisa efisiensi penurunan logam $\mathrm{Pb}$ dan $\mathrm{Zn}$ pada proses composting, sedangkan analisa statistik menggunakan uji ANOVA One-way dan Kruskal Wallis untuk mengetahui apakah ada perbedaan nyata pada variasi komposisi bahan composting yang digunakan.

\section{HASIL DAN PEMBAHASAN}

\subsection{Kondisi Composting}

\subsubsection{Perubahan Suhu}

Suhu pada proses composting diamati setiap hari selama 35 hari, hasil pengamatan suhu disajikan pada Gambar 3.1. Suhu composting mengalami kenaikan dan mencapai suhu tertinggi selama proses pengomposan pada hari pertama dan hari kedua. Suhu pada reaktor R-3 meningkat hingga mencapai $36^{\circ} \mathrm{C}$ pada hari pertama, reaktor R-5 dan R-6 meningkat menjadi $37,5^{\circ} \mathrm{C}$, sedangkan R- 
1, R-2, dan R-4 mengalami kenaikan suhu pada hari kedua R-1 meningkat menjadi $34^{\circ} \mathrm{C}, \mathrm{R}-2$ menjadi $35^{\circ} \mathrm{C}$, dan R-4 meningkat menjadi $36^{\circ} \mathrm{C}$. Peningkatan suhu selama proses composting merupakan indikasi telah terjadi peningkatan jumlah populasi dan aktivitas mikroorganisme dalam matrik kompos (Zhang, dkk, 2011 dalam Mizwar, 2016). Aktivitas mikroorganisme dalam mendekomposisi bahan organik menghasilkan panas, $\mathrm{CO}_{2}$ dan uap air. Panas yang dihasilkan tersimpan dalam tumpukan sehingga menyebabkan suhu tumpukan meningkat (Barakwan, 2017).

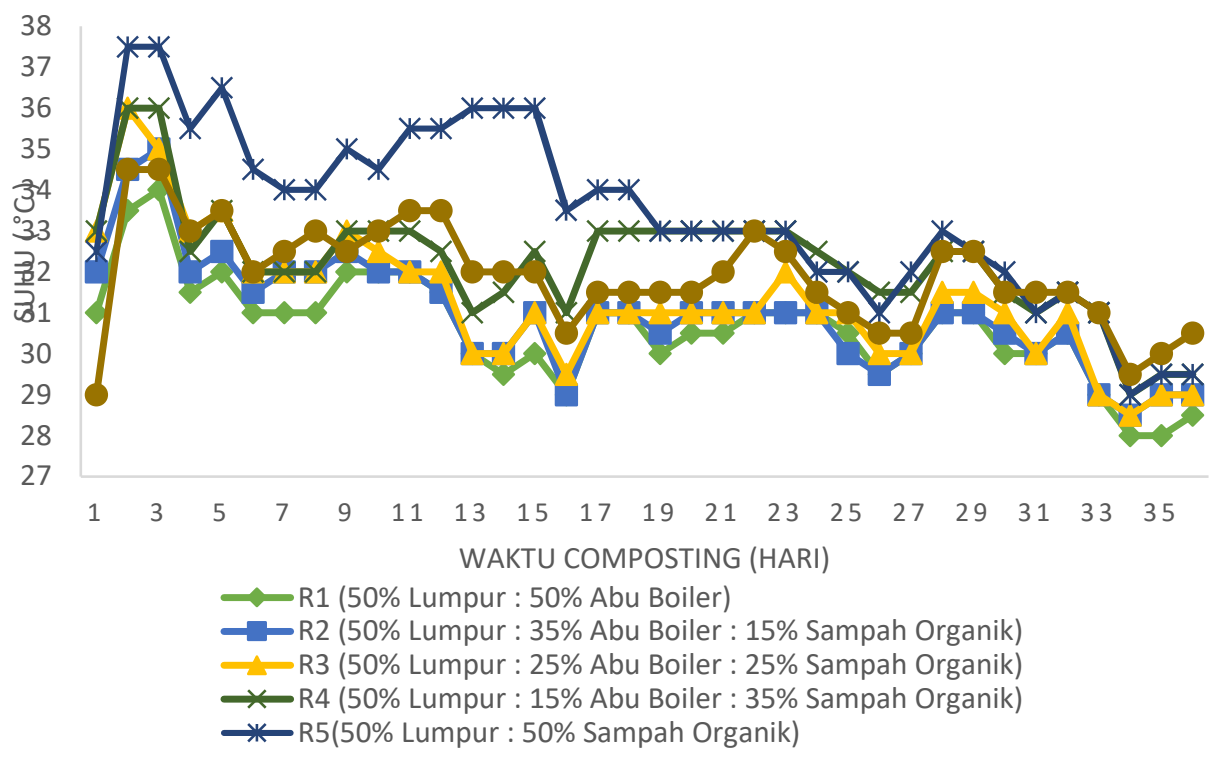

Gambar 3.1 Grafik Pengamatan Perubahan Suhu

Suhu composting selama 35 hari mengalami fluktuasi seperti yang terlihat pada Gambar 4.1. Pada minggu pertama pengomposan suhu mengalami kenaikan yang signifikan dan berangsur-angsur mengalami penurunan suhu pada minggu ke empat dimana pada akhir pengomposan suhu semua reaktor mendekati suhu ruang $\left(27^{\circ} \mathrm{C}\right)$. Selama proses composting suhu berada dalam regim mesofilik $\left(25^{\circ} \mathrm{C}-45^{\circ} \mathrm{C}\right)$, menurut Sayara, dkk, (2011), ini merupakan kondisi terbaik untuk mendukung pertumbuhan dan perkembangan mikroorganisme.

Bahan-bahan organik dalam kompos akan diuraikan menjadi $\mathrm{CO}_{2}$, uap air dan panas oleh mikroba yang aktif dengan memanfaatkan oksigen didalam kompos. Penguraian bahan organik ini dapat mempengaruhi suhu composting, semakin banyak bahan yang telah terurai maka suhu composting secara perlahan mengalami penurunan. Kondisi menunjukkan terjadinya proses pematangan kompos tingkat lanjut, yaitu pembentukan komplek liat humus (Isroi, 2008).

\subsubsection{Perubahan $\mathrm{pH}$}

Pada awal proses pengomposan $\mathrm{pH}$ bahan composting berkisar antara 6,67-7,88. Menurut Hayati, dkk (2015) bakteri decomposer mampu bertahan hidup dengan baik pada kondidi pH kisaran 6,5 - 7,5 karena pada kondisi ini unsur hara tanah tersedia dalam jumlah yang cukup banyak. Dapat dilihat pada Gambar 3.2 dibawah ini bahwa pada hari ke-14 pH pada reaktor R-1 sampai R-5 mengalami penurunan. 


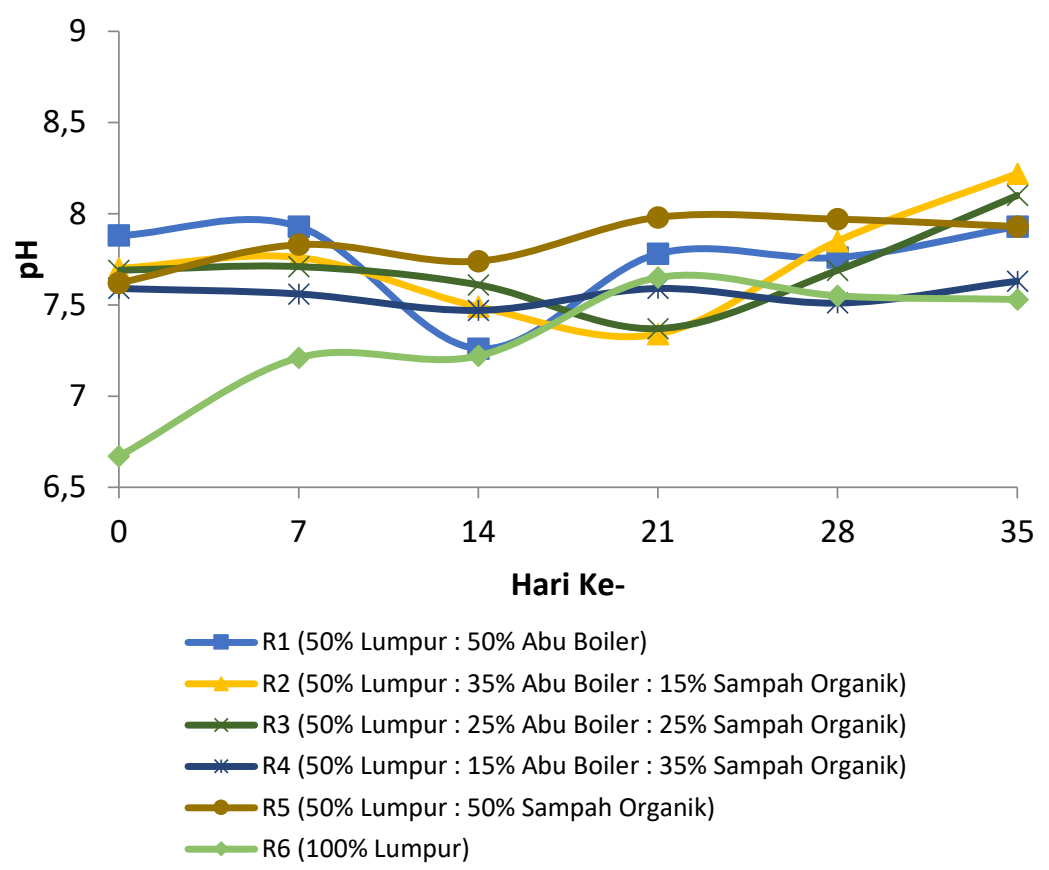

Gambar 3.2 Grafik Pengamatan $\mathrm{pH}$

Menurut Meunchang,dkk (2005) dalam Ismayana (2010) pada tahap awal proses composting aktivitas mikroorganisme menghasilkan reduksi dari ammonium $\left(\mathrm{NH}_{4}{ }^{+}\right)$dan asam organik sehingga mengakibatkan penurunan nilai $\mathrm{pH}$ kompos. Pada hari ke-21 sampai dengan hari ke-35 pH meningkat perlahan menuju netral hingga sedikit basa pada reaktor R-1, R-2, R-3, dan R-4. Kenaikan $\mathrm{pH}$ disebabkan karena terjadinya penguraian protein menjadi ammonia $\left(\mathrm{NH}_{3}\right)$ (Supadma, 2008). Sedangkan reaktor R-5 dan R-6 mengalami sedikit penurunan nilai pH, menurut Baharuddin,dkk., (2009) hal ini dikarenakan adanya oksidasi enzimatik senyawa anorganik.

\subsubsection{Kandungan Kadar Air}

Kadar air merupakan faktor penting selama proses pengomposan karena kadar air yang terlalu rendah atau terlalu tinggi dapat mempengaruhi efisiensi pengomposan. Menurut Richard (1996) dalam Hakim (2013) kadar air ideal untuk proses pengomposan adalah 40\% - 60\%. Pada awal proses composting semua reaktor memiliki kadar air dibawah kondisi optimum, dari hari ke-0 hingga hari ke-7 hanya reaktor R-6 yang memiliki kadar air optimum yaitu 57,72\% pada hari-0 dan 43,46\% pada hari-7. Pada hari ke-14 hanya reaktor R-5 dan R-6 yang memiliki kadar air optimum yaitu 40,75\% dan 47,62\%. Pada hari ke-21 selain reaktor R-5 dan R-6, reaktor R-4 juga memiliki kondisi kadar air yang optimum yaitu 42,02\%; 45,22\%; dan 44,91\%. Pada hari ke-28 dari ke enam reaktor tidak ada satu reaktor pun yang memiliki kadar air optimum. Penurunan kadar air ini berkaitan dengan aktivitas mikroorganisme dan cuaca yang sangat panas sehingga meningkatkan angka penguapan. Untuk mengatasi hal tersebut, peneliti melakukan penyemprotan hingga bahan composting cukup lembab. Pada hari terakhir pengomposan kadar air seluruh reaktor secara keseluruhan yaitu 32,07\%; 32,83\%; 33,72\%; 40,31\%; 43,33\%; dan 47,74\%. Menurut SNI 19 - 7030 - 2004 batas maksimum kadar air pada kompos adalah 50\%. 


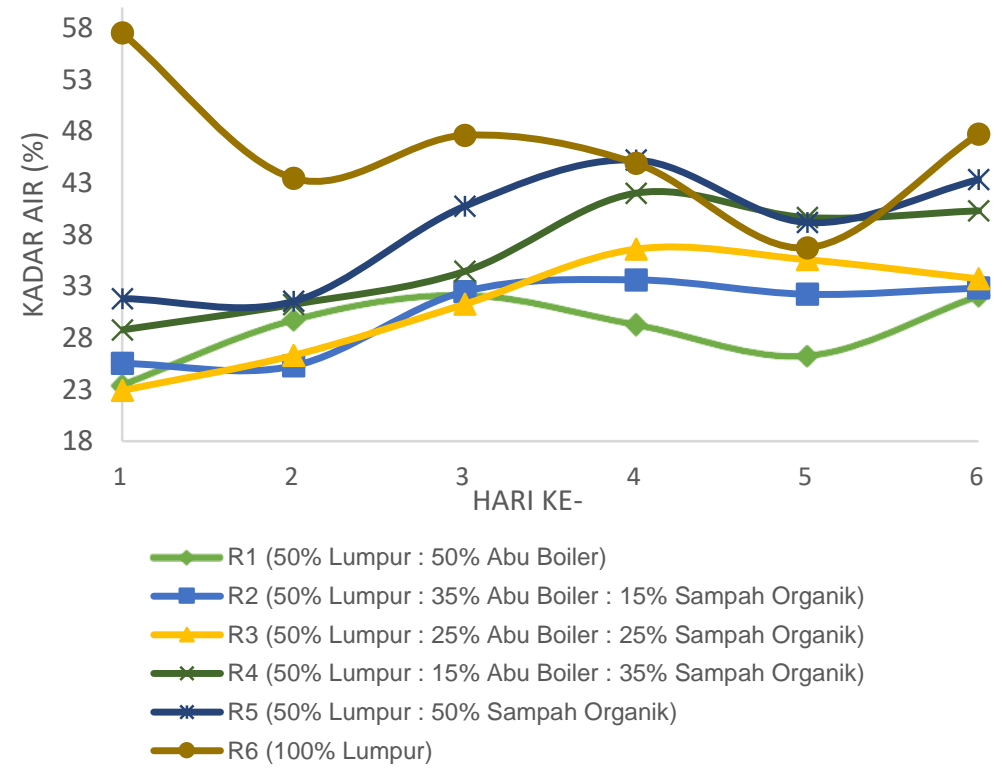

Gambar 3.3 Grafik Pengukuran Kadar Air

\subsection{Analisia Penurunan Konsentrasi Logam Pb dan $\mathrm{Zn}$}

Hasil pengamatan konsentrasi logam berat $\mathrm{Pb}$ dan $\mathrm{Zn}$ pada Tabel 4.1 menunjukkan penurunan konsentrasi logam berat pada Reaktor 5 lebih efisien dibandingkan dengan Reaktor lainnya. Efisiensi penurunan logam berat pada Reaktor 5 ditunjukkan dengan adanya nilai positif pada hasil perhitungan efisiensi seperti yang tertera pada Tabel 4.1. Hal ini dikarenakan Reaktor 5 memiliki komposisi sampah organik lebih banyak daripada reaktor lain. Menurut Salam, dkk (1998) gugus fungsional di dalam bahan organik jika terionisasi dapat bersifat aktif dalam menjerap logam berat.

Tabel 3.1 Efisiensi Penurunan Logam $\mathrm{Pb}$ dan $\mathrm{Zn}$

\begin{tabular}{cccccccc}
\hline & & \multicolumn{6}{c}{ Efisiensi Penurunan(\%) } \\
\cline { 2 - 8 } & ke- & Reaktor & Reaktor & Reaktor & Reaktor & Reaktor & Reaktor \\
& 7 & -9.38 & -24.57 & -11.91 & -5.18 & 17.21 & -112.01 \\
& 14 & -44.86 & -129.03 & -58.14 & -29.92 & 9.31 & -15.33 \\
& & $\mathbf{2}$ & $\mathbf{3}$ & $\mathbf{4}$ & $\mathbf{5}$ & $\mathbf{6}$ \\
\hline & 21 & -124.94 & -50.12 & 13.13 & -19.98 & 13.59 & -31.21 \\
& 28 & 60.45 & 57.36 & 41.91 & 30.81 & 60.51 & 8.97 \\
& 35 & -179.02 & 5.04 & -182.86 & -14.15 & -9.81 & -176.16 \\
\hline & & & & & & & \\
\hline & 7 & -7.67 & -7.03 & -4.74 & -18.70 & -7.80 & -62.70 \\
& 14 & -39.50 & -54.60 & -35.52 & -50.19 & 1.37 & -51.45 \\
& 21 & -41.12 & -38.28 & -31.45 & -68.05 & -39.56 & -71.14 \\
& 28 & -63.65 & -35.85 & -32.14 & -79.77 & -56.74 & -68.45 \\
& 35 & -71.99 & -43.16 & -45.86 & -71.89 & -65.73 & -90.82 \\
\hline
\end{tabular}


Keterangan :

Nilai (+) menunjukkan adanya penurunan konsentrasi

Nilai (-) menunjukkan tidak adanya penurunan konsentrasi

Menurut Tan (1993) Menurunnya pH dapat meningkatkan kelarutan logam-logam. Pada Tabel 4.2 dapat dilihat bahwa nilai Reaktor 5 memiliki nilai $\mathrm{pH}$ rata-rata paling tinggi yaitu 7,89. Nilai $\mathrm{pH}$ yang lebih tinggi dapat mengaktifkan gugus fungsional dalam mengikat logam berat $\mathrm{Pb}$ dan $\mathrm{Zn}$. Pada proses composting aktivitas mikroorganisme berpengaruh terhadap penurunan logam berat, akan tetapi pada penelitian mengenai data populasi mikroorganisme.

Tabel 3.2 Hasil Pengamatan $\mathrm{pH}$ selama Composting

\begin{tabular}{ccccccc}
\hline & \multicolumn{7}{c}{ pH } & & & & \\
\hline Minggu ke- & R-1 & R-2 & R-3 & R-4 & R-5 & R-6 \\
\hline 1 & 7.93 & 7.76 & 7.71 & 7.56 & 7.83 & 7.21 \\
2 & 7.26 & 7.49 & 7.61 & 7.47 & 7.74 & 7.22 \\
3 & 7.78 & 7.34 & 7.37 & 7.59 & 7.98 & 7.65 \\
4 & 7.76 & 7.85 & 7.69 & 7.51 & 7.97 & 7.55 \\
5 & 7.93 & 8.22 & 8.1 & 7.63 & 7.93 & 7.53 \\
Rata-Rata & 7.73 & 7.73 & 7.70 & 7.55 & 7.89 & 7.43 \\
\hline
\end{tabular}

Nilai suhu rata-rata Reaktor 5 paling tinggi dibandingkan reaktor-reaktor lainnya yaitu $34,33^{\circ} \mathrm{C}$. Nilai ini mendekati nilai optimum aktivitas mikroorganisme. Menurut Richard (1996) suhu tinggi menyebabkan aktivitas mikroorganisme mengalai peningkatan, sehingga penguraian bahan organik menjadi lebih cepat yang secara tidaklangsung meningkatkan gugus fungsional yang dapat menjerap logam berat. Dari beberapa faktor yang telah dijabarkan sebelumnya dapat disimpulan bahwa komposisi bahan composting pada Reaktor 5 yaitu 50\% lumpur WWTP dan 50\% bahan organik merupakan komposisi terbaik untuk menurunkan logam $\mathrm{Pb}$ dan $\mathrm{Zn}$.

\subsubsection{Penurunan Logam Pb Dan Zn Dalam Statistik}

Perhitungan statistik penurunan Zn dilakukan dengan menggunakan Uji ANOVA one-way menggunakan spss. Pengujian ANOVA one-way dapat dilakukan jika data yang digunakan memenuhi syarat uji normalitas dan homogenitas. Pada perhitungan uji normalitas data penurunan $\mathrm{Zn}(\operatorname{sig}>0,05)$ dapat disimpulkan bahwa semua reaktor dengan variasi komposisi bahan composting memiliki distribusi data normal dengan tingkat signifikansi 5\%, artinya data penurunan Zn yang dianalisa memiliki sebaran merata dan dapat mewakili data penelitian secara keseluruhan. Hasil uji homogenitas menunjukkan nilai sig. $(0,265)$ lebih besar dari 0,05 artinya data penurunan $\mathrm{Zn}$ memiliki varian karakteristik yang sama, sehingga dapat dilanjutkan ke uji ragam one-way ANOVA. Hasil analisis ragam one-way ANOVA penurunan $\mathrm{Zn}$ semua reaktor tidak berbeda nyata (nilai sig. > 0,05), maka data penurunan $\mathrm{Zn}$ tidak memerlukan uji lanjutan.

Data penurunan $\mathrm{Pb}$ tidak dapat diuji menggunakan analisis one-way ANOVA karena hasil uji normalitas data tidak normal $(\mathrm{p}<0,05)$ dan hasil uji homogenitas data memiliki varian yang tidak sama $(\mathrm{p}<0,05)$, maka peneliti menggunakan uji Kruskal Wallis sebagai alternatif uji statistik. Uji Kruskal Wallis merupakan 
uji non parametric sehingga data yang diuji tidak harus memiliki sebaran normal. Hasil uji statistik pada metode Kruskal Wallis menunjukkan (Asymp. Sig. < 0,05) artinya ada perbedaan nyata.

\section{KESIMPULAN DAN SARAN}

\subsection{Kesimpulan}

Dari penelitian yang telah dilakukan, maka dapat disimpulkan bahwa :

1. Kondisi composting secara keseluruhan terpenuhi dan berlangsung dengan baik selama proses pengomposan.

2. Variasi bahan composting pada Reaktor 5 (50\% bahan organik dan $50 \%$ lumpur WWTP) merupakan komposisi bahan paling baik diantara Reaktor lain dalam menurunkan logam $\mathrm{Pb}$ dan $\mathrm{Zn}$. Dari perhitungan efisien secara manual reaktor 5 memiliki nilai positif pada perhitungan efisiensi lebih banyak daripada Reaktor lainnya. Pada perhitungan statistik menggunakan uji ANOVA one-way parameter $\mathrm{Zn}$ tidak memiliki perbedaan nyata antar varian sehingga dalam penurunan logam $\mathrm{Zn}$ variasi komposisi tidak terlalu berbepangaruh, sedangkan hasil perhitungan statistik parameter $\mathrm{Pb}$ dengan menggunakan uji Kruskal Wallis menunjukkan adanya perbedaan nyata, artinya variasi komposisi berpengaruh terhadap penurunan $\mathrm{Pb}$.

\subsection{Saran}

Berikut ini adalah beberapa saran yang dapat dilakukan pada penelitian selanjutnya :

1. Perlu dilakukan penelitian lanjutan dengan waktu composting lebih lama

2. Perlu dilakukan penelitian lanjutan tentang aplikasi kompos yang dihasilkan terhadap tanah dan tanaman

3. Perlu dilakukan penelitian lanjutan mengenai pertumbuhan populasi mikroorganisme selama composting

\section{DAFTAR PUSTAKA}

Baharuddin, A. S.2009. Co-Composting of Empty Fruit unches and Partially Treated Palm Oil MillEffluents in Pilot Scale. International Journal of Agricurtural Research 4.

Darmawati J. S., Siregar Abdul Rasid dan Nursamsi. 2014. Pengaruh Pemberian Limbah Padat (Sludge) Kelapa Sawit Dan Pupuk Organik Cair Terhadap Pertumbuhan Dan Produksi Tanaman Jagung Manis (Zea Mays Saccharata.). Fakultas Pertanian UMSU.

Hayati, F., Mizwar, A., Jumar. 2015. Pemanfaatan Limbah Lumpur IPAL Pabrik Karet sebagai Bahan Baku Composting. Jukung Jurnl Teknik Lingkungan Volume 1 Nomor 1.

Isroi. 2008. Kompos. Bogor : Balai Penelitian Bioteknologi Perkebunan Indonesia.

Kusmiyarti, T. B. 2013. Kualitas Kompos dari Berbagai Kombinasi Bahan Baku Limbah Organik. AGROTROP. 3 (1) : $83-92$.

Lasryza, Ayu dan Sawitri, Dyah. 2012. Pemanfaatan Fly Ash batubara sebagai Absorben Emisi Gas CO Kendaraan Bermotor. Jurnal Teknik Pomits Volume 1 Nomor 1.

Meunchang S., Panichsakpatana S, Weaver RW. 2005. Co-composting of Filter Cake and Bagasse; by products from sugar mill. Bioresour Technol. 96:437-442 
Mizwar, A. dan Trihadiningrum, Y., 2014. Potensi Bioremediasi Tanah Terkontaminasi Polycyclic Aromatic Hydrocarbons dari Batubara dengan Composting, Prosiding Seminar Nasional Waste Management II, Institut Teknologi Sepuluh Nopember, Surabaya, hal. 251-264

Naibaho, M. P., 1996. Teknologi Pengolahan Kelapa Sawit. Pusat Penelitian Kelapa Sawit, Medan.

Peraturan Menteri Lngkungan Hidup Nomor 101 Tahun 2014 Tentang Pengelolaan Bahan Berbahaya dan Beracun

Perdana, Jeremia. 2012. Uji Resistensi Dan Uji Biodegradasi Logam Berat (Pb, Zn, Dan Hg) Oleh Isolat Bakteri Lumpur Pantai Kenjeran. Skripsi. Universitas Airlangga.

Priyambada, Gunadi., Yeni, Elvi., Andesgur, Ivnaini. 2015. Studi pemanfaatan Lumpur, Abu Boiler, dan Serat (Fiber) Kelapa Sawit sebagai Kompos Menggunakan Variasi Effective Microorganisme (EM-4). JOM FTEKNIK Volume 2 Nomor 2.

Putra, Angara. Yenie, Elvi., dan Elystia, Shinta. 2016. Pemanfaatan Limbah Pabrik Kelapa Sawit sebagai Kompos dengan Variasi Penambahan Dosis Abu Boiler serta Penggunaan Bioaktivator EM-4. Jom Fteknik Volume 3 Nomor 1.

Sari, G. L., Mizwar, A., dan Trihadiningrum, Y. 2015. Potensi Co-composting untuk Bioremediasi Tanah Terkontaminasi Polycyclic Aromatic Hydrocarbon (PAH). Prosiding Seminar Nasional Manajemen Teknologi XXII: Surabaya. 
$\underline{\text { halaman ini sengaja dikosongkan }}$ 